\title{
Karel Boženek - opavský muzikolog a muzeolog, zakladatel hudebněhistorického oddělení Slezského zemského muzea
}

\section{Karel Boženek - Musicologist and Museologist from Opava, Founder of a Musical-History Department of the Silesian Museum}

Karel Steinmetz / karel.steinmetz@osu.cz

Department of Music Education, Faculty of Education, University of Ostrava, Ostrava, CZ

\begin{abstract}
Karel Boženek is one of the most important experts in the field of musical culture of so-called Czech Silesia. In the Museum of the Silesian Region in the town of Opava he built a musicological workplace led by him in 1967-1987. He worked as a reseacher and a pedagogue at the Institute of History and Museology at the Faculty of Philosophy and Science of the Silesian University in Opava (1993-2010) after a short career in the Dramaturgy of the Opera and Ballet at the State Theater in Ostrava and as a classical music dramaturgist in Pragokoncert (1988-1993). At present, the Department of Music Education of the Faculty of Education of the University of Ostrava uses his extensive knowledge and rich experience in the research of musical culture in Silesia for scientific student education. He serves as a mentor for PhD students and as na external consultant of the Center for Regional Music Studies.
\end{abstract}

\section{Keywords}

musical regional science in Silesia, Karel Boženek, Silesian Museum in Opava, musical-historical research in Czech Silesia 
Karel Boženek (*1938) patř́ spolu s Miroslavem Malurou (1937-2000) k nejvýznamnějším opavským hudebním historikům. Oba zde začínali svou muzikologickou kariéru začátkem šedesátých let minulého století po absolutoriu svých vysokoškolských studií (opavský rodák Miroslav Malura se do svého rodného města vrátil po promoci na Filozofické fakultě brněnské univerzity jako vedoucí umělecko-historického oddělení Slezského kulturního střediska v Hradci nad Moravicí a tajemník Beethovenovy společnosti v Československu, Karel Boženek, po maturitě na valašskokloboucké jedenáctiletce studoval na katedře hudební vědy a výchovy Filozofické fakulty Univerzity Palackého v Olomouci ${ }^{2}$ a v roce 1963 převzal po Malurovi funkci tajemníka Beethovenovy společnosti na zámku v Hradci nad Moravicí a stal se také redaktorem časopisu Československá beethoveniana). ${ }^{3}$ Oba pak téměř dvacet let pracovali v muzeích; Boženek v roce 1967 založil a vedl do roku 1987 muzikologické oddělení Slezského muzea v Opavě, Malura pak poté, co z politických důvodů musel odejít po šestiletém působení na ostravské katedře hudební výchovy Pedagogické fakulty, byl v letech 1973-1989 pracovníkem Vlastivědného muzea okresu Karviná v Českém Těšíně, než se mohl vrátit zpět na ostravskou fakultu.

Jaká ale byla situace v oblasti hudebněhistorického bádání v českém Slezsku a konkrétně v Opavě před příchodem obou mladých muzikologů do tohoto města? Již na konci 19. století zde vznikla Matice opavská, která v letech 1892 až 1936 vydávala první vědecké periodikum v českém Slezsku Věstnik Matice opavské, předchůdce dodnes vycházejícího Slezského sborniku. Po zrušení Matice opavské byl v květnu 1948 v Opavě založen Slezský studijní ústav, vedený Bohumilem Sobotíkem, a o rok a půl později v rámci tohoto ústavu vznikl referát pro hudební vědu. Místo referenta tohoto resortu bylo obsazeno brněnským absolventem hudební vědy dr. Oldřichem Petrášem, a tím vlastně byla vytvořena základna pro organizování systematického hudebněvědného výzkumu ve Slezsku. ${ }^{4}$ Po odchodu Petráše ze Slezského studijního ústavu v roce 1951 suplovala do konce roku 1953 hudební historii dr. Hana Podešvová, hudební folkloristiku prof. Antonín Satke. V té době pracovali na muzikologickém průzkumu pramenů na Ostravsku a v českém Slezsku posluchači hudebněvědného semináře Filozofické i Pedagogické fakulty Masarykovy univerzity pod vedením Jana Racka a Bohumíra Štědroně. Zároveň studenti souběžně prováděli s Bohumírem Indrou a Vladimírem Scheuflerem sběr historických písní na Hlučínsku. ${ }^{5}$ Tyto sběry pak daly základ Slezského hudebního archivu, ${ }^{6}$ který pak byl ještě obohacen o materiály bývalé Společnosti Pavla Kř́žzovského v Opavě.

Začátkem roku 1954 nastoupil na neobsazené místo hudebního referenta Slezského studijního ústavu po Oldřichu Petrášovi dr. Ivo Stolařík, který započal podrobnou evi-

1 Absolvoval u Jana Racka a Bohumíra Štědroně v roce 1960, po obhájení diplomové práce Lašské tance Leoše Janáčka.

2 Studium na olomoucké katedře hudební vědy a výchovy Filozofické fakulty vedené Robertem Smetanou ukončil obhájením práce Národnost v hudbě (vedoucí práce Vladimír Hudec) v roce 1960.

3 Časopis vycházel jednou ročně v letech 1964-1968.

4 Srov. BOŽENEK, Karel. Český hudebněhistoriografický výzkum regionu bývalého rakouského Slezska. In Acta historica et museologica Universitatis Opaviensis, 4, 1999, s. 8.

5 Tamtéž.

6 Tamtéž. 
denci slezských hudebníků a hudebněhistorický i hudebněfolkloristický výzkum slezské oblasti formou dotazníkové akce. ${ }^{7}$ Do konce dubna 1960 tak získal Slezský hudební archiv 3364 inventárních čísel přírůstků (převážně fondy Frýdek-Místek, Fryštát, Opava, Stará Ves, Moravská a Slezská Ostrava, pozůstalosti Milana Balcara, Arthura Könemanna, Rudolfa Wünsche, Eduarda Marhuly, Václava Kálika a dalších). Všechny přírůstky ve Slezském hudebním archivu a Archivu lidové písně byly inventarizovány a katalogizovány. Ivo Stolařík také formuloval a upřesnil úkoly referátu pro hudební vědu ve stati K úkoliom referátu pro hudebni vědu Slezského studijniho ústavu (In Zprávy SSÚ č. 62/1954).

Začátkem 60. let minulého století změnilo prezidium Československé akademie věd zaměření opavského Slezského studijního ústavu na současné dějiny dělnického hnutí, a proto byla zrušena místa pracovníků uměnovědných referátů. Dr. Ivo Stolařík v roce 1963 odchází z Opavy na místo ředitele Státní filharmonie Ostrava. Vzniklá absence institucionálního zaštítění hudebněhistorické práce byla pocitována v celé oblasti velmi silně, a tak došlo k pokusu rozvinout hudebně muzejní činnosti na zámku Hradci u Opa$\mathrm{vy},{ }^{8}$ a to v souvislosti s rozvíjením beethovenovských tradic ${ }^{9}$ a budováním nové expozice slezských hudebníků a zámecké interiérové expozice se zaměřením na hudební tradice 18. a 19. století. Hlavním iniciátorem těchto akcí byl dr. Miroslav Malura, kterému po příchodu z dvouleté základní vojenské služby v této činnosti velmi pomáhal Karel Boženek. Ten nastoupil začátkem února 1963 na místo referenta na Zámku Hradec, hudebního muzea a galerie. Celková koncepce tohoto zařízení však nedovolovala rozšířit činnost i na širší oblast hudebněmuzejní práce (budovala se sbírka hudebních nástrojů, instituce umožnila činnost Beethovenovy společnosti a Karel Boženek se stal redaktorem časopisu Československá beethoveniana). ${ }^{10} \mathrm{~V}$ sídle sekretariátu Beethovenovy společnosti na zámku v Hradci u Opavy bylo založeno Dokumentační středisko beethovenových památek v ČSSR a vypracovala se základní koncepce generálního katalogu těchto památek.

7 Srov. kapitolu Př́nos Iva Stolařika k rozvoji hudebni historiografie Slezska a Ostravska v monografii STEINMETZ, Karel - BOŽENEK, Karel - MAZUREK, Jan. Ivo Stolařik. Osobnost hudebního Ostravska. Ostrava: Montanex, 2006, s. 23.

8 Dnes Hradec nad Moravicí. Srov. BOŽENEK, Karel. Hudební život na Zámku Hradci. Listy Hradce, Hradec u Opavy 1965.

9 V srpnu 1960 se konala na zámku Hradci konference československých muzikologů zabývajících se beethovenovskou problematikou. Tématem konference byl stav beethovenovského bádání u nás a vytyčení dalších směrů výzkumu. Na této konferenci se ustavila komise pro studium vztahů Ludwiga van Beethovena k českým zemím a ke Slovensku, která v roce 1962 na konferenci v Karlových Varech přijala název Beethovenova společnost v ČSSR, jejíž předsedou se stal prof. Jan Racek a tajemníkem Miroslav Malura. Tato společnost pracovala ve třech komisích: a) hudebně vědné - sdružující badatele zabývající se hudebně historickým výzkumem, b) interpretační - dávající prostory beethovenovským interpretům a c) popularizační - koordinující pořádání beethovenovských festivalů na území tehdejšího Československa. Z aktivních členů šedesátých let, kteří „nastartovali“ činnost Beethovenovy společnosti na patřičné vědecké i umělecké úrovni, je nutno jmenovat Jana Racka, Rudolfa Pečmana, Jiř́ho Fukače, Karla Nejdla, Vladimíra Karbusického, Bohumila Plevku, ze Slovenska Lubu Ballovou, Zoltána Hrabusaye a Rudolfa Macudzinského a ze zdejší oblasti Ivana Měrku, Ivo Stolaříka a Karla Boženka. Z interpretů to byli zvl. František Rauch, Ludvík Kundera, Václav Holzknecht a mnoho dalších. Během rozvoje práce přistupovali i další spolupracovníci Jaroslav Vanický, Vladimír Karbusický, Emil Hradecký, Marie Tarantová, Josef Tvrdoň a další.

10 Časopis, který přinášel mj. odborné studie a zprávy o činnosti, vycházel jedenkrát za rok v letech 1964-1968. 
V průběhu šedesátých let, v souvislosti s celkovým uvolněním v kulturněpolitické situaci v našem státě, nastala vhodná doba k vytvoření lepšího institucionálního zázemí pro hudebněhistorický výzkum českého Slezska i širšího Ostravska. V opavském Slezském muzeu se podařilo v průběhu roku 1967 otevřít hudebněhistorické oddělení a jeho vedoucím a zpočátku jediným pracovníkem se stal Karel Boženek.

Historie Slezského zemského muzea, v němž se shromažd'ovaly sbírky přrírodovědného materiálu, doplněné o hmotné doklady minulosti všech oborů lidské činnosti sahá do roku 1814. Zde nashromážděný materiál měl sloužit k poznání přírody a kultury rakouského Slezska. Po vzniku Československa se Slezské zemské muzeum zařadilo jako významná muzejní instituce po bok Národního muzea v Praze a Moravského zemského muzea v Brně. Zatímco v Praze existovalo hudební oddělení vedené Emilem Axmanem už od roku 1913 a v Brně za ředitelského působení v muzeu Jaroslava Helferta, bratra muzikologa Vladimíra Helferta, byl za první republiky budován Hudební archiv zemského muzea v Brně, ${ }^{11}$ v Opavě došlo ke zřízení muzikologického oddělení až na konci šedesátých let minulého století, a to díky změně zaměření Slezského studijního ústavu Československé akademie věd. ${ }^{12}$

Základní úkoly slezské hudební historiografie vytyčené Ivo Stolaříkem zůstaly nezměněny i pro pracovní náplň tohoto muzejního pracoviště. Zároveň však vystoupily naléhavě do popředí problémy hudebněmuzejní práce spojené s nutností tezaurace a prezentace hudebněmuzejního materiálu. Tento požadavek se stal aktuálním také proto, že při současném rozvoji hudebněhistorické práce u nás, a to jak v souvislosti s mezinárodními soupisy hudebních památek, tak i s výzkumem hudebněvědeckých institucí zůstal obraz Slezska mimo toto dění vzhledem k roztř́íšěnosti a nezpracovanosti materiálu.

Karel Boženek si uvědomoval, že organizace nového hudebněhistorického pracoviště Slezského muzea si vyžaduje před započetím vlastní práce v terénu vyřešení problematiky hudebněhistoriografického výzkumu na území československého Slezska, ujasnění návaznosti na dosavadní hudebněvědnou činnost, která probíhala bez speciálního hudebně- muzeologického zaměření a zapojení do komplexu hudebněhistorických pracovišt muzejního typu v tehdejším Československu. Ve studii Český hudebně historiografický výzkum regionu bývalého rakouského Slezska ${ }^{13}$ o tom později napsal: „Požadavek na vznik hudebněhistorického pracoviště speciálně zaměřného $k$ muzejni činnosti vystupoval do popredi během celého vývoje odborných ústavů a instituci v Opavě a nejevil se nikdy potrebou pouze teoretickou, spekulativní. Nutnost jeho zř́izeni byla pocitována pri práci s archivním i muzejním materiálem hudebního charakteru, který vyžadoval odborné zpracováni. Nálezy tohoto materiálu, hudebni tradice Slezska a jejich rozvoj v současném kulturním životě daly vzniknout společenské

11 Srov. HELFERT, Vladimír. Hudební archiv Zemského muzea v Brně. In Věstnik moravského zemského muzea v Brně, 1921, č. I-III, s. 27 či HELFERT, Vladimír. Státní hudebně historický ústav. Praha: Hudební matice umělecké besedy, 1945.

12 Po listopadových změnách roku 1989, resp. po transformaci Československé akademie věd na Akademii věd České republiky se stal Slezský ústav jedním ze tří hlavních oddělení Slezského zemského muzea, jako oddělení historického výzkumu, vedle oddělení přírodních věd a oddělení věd společenských.

13 BOŽENEK, Karel. Český hudebně historiografický výzkum regionu bývalého rakouského Slezska, op. cit. 
poptávce, která již nemohla být pokryta činností nejbližšiho pracoviště tohoto typu, tj. hudebnim oddělením Moravského muzea v Brně."14

V práci hudebního oddělení proto došlo ke konkretizaci předběžného směru výzkumu, vymezení sběrné oblasti a bylo započato také s prováděním sběru a vědeckého zpracování získaného materiálu. Dominantou se stala centralizace hudebních materiálů archivní povahy. Proto byl archivní nehudební materiál vztahující se k hudební historii, uložený v okresním a státním archivu zajištěn ve spolupráci s těmito institucemi. Také se začalo se sběrem hudebních nástrojů a trofejních předmětů. U hudebních nástrojů se sběr zaměřil na sbírkové předměty slezské provenience s charakterem dokumentačním a také na nástroje s uměleckohistorickou cenou. Hlavním cílem práce hudebního oddělení však nebyl jenom samotný materiál, ale znějící hudba v historicky správné interpretační podobě se zhodnocením všech filiačních vlivů, dobových prvků, kritérií periodizačních, včetně zařazení specifického přínosu hudební kultury této oblasti do kontextu národního a západoevropského. Po vzoru jiných uměnovědných disciplín šlo i zde o odstranění bílých ploch na hudebněhistorické mapě a zpracování hudební topografie s akceptováním veškerých specifičností hudební kultury Slezska.

Při vymezování sběrné oblasti pro hudebně historiografické pracoviště vycházel Boženek především z celkového poslání a zaměření dokumentační činnosti Slezského muzea na oblast Slezska a Ostravska. Samotné historické utváření této oblasti je problémem složitým a ovlivňovalo a komplikovalo i jednotlivé složky hudebně historického vývoje. Mimo historické vlivy zde působilo i přirozené přrírodní oddělení této oblasti od Moravy a její otevření do regionů, které jsou v současné době mimo naše státní hranice. Z toho také vyplývalo, že výzkum nebylo možno provádět bez srovnávacího hlediska k dosavadním výsledkům bádání muzikologů polských a německých. Proto také při vymezení oblastí vyznačujících se specifickou hudební kulturou se respektoval vývoj politických hranic, výsledky bádání o dějinách osídlení tohoto území a s tím souvisejících jazykových proměn.

Nové úkoly, které stály před Karlem Boženkem, ho přivedly k rozhodnutí, aby si své hudebněhistorické vzdělání rozšíŕil ještě o teoretické zázemí z oboru muzeologie. Proto se přihlásil k postgraduálnímu studiu na Filozofické fakultě tehdejší Univerzity Jana Evangelisty Purkyně tohoto oboru, který tehdy prosadil v Brně Zdeněk Zbyslav Stránský. ${ }^{15}$

Kromě heuristické práce při sběru pramenného materiálu byla důležitá v muzejní činnosti hlavně jejich prezentace ve výstavní činnosti. Na tomto místě připomeňme velké výstavy ve Slezském muzeu organizované Karlem Boženkem, např. v roce 1973 Varhany Krnov (1873-1973) či Minulost a současnost hudebni kultury Opavska a Ostravska roku 1977.

Při práci ve Slezském muzeu se Boženek plně zapojil do opavského kulturního života. Úzce spolupracoval s operním souborem Slezského divadla v Opavě jako člen jeho umělecké rady, odborný poradce a recenzent operních představení. Také působil jako soudní znalec v oboru hudební nástroje, člen řídícího výboru mezinárodní soutěže o cenu

14 Tamtéž, s. 11.

15 Po postgraduálním studiu muzeologie na brněnské Filozofické fakultě v letech 1967-1970 vykonal Karel Boženek ještě v roce 1970 rigorózní řízení z Dějin a teorie hudby na Pedagogické fakultě v Ostravě před touto komisí: doc. Vladimír Gregor, doc. Antonín Tučapský a prof. Josef Schreiber (disertace Opera ve Slezsku). 
Beethovenova Hradce či člen výboru celostátní soutěže varhaníků v Opavě. Při opavském muzikologickém pracovišti založil soubor historických hudebních nástrojů Collegium Musicum Musei Silesiae, který interpretoval skladby z hudebněhistorických sběrů. Soubor tvořili většinou profesionální hudebníci ze Slezského divadla v Opavě a ostravského Státního divadla a Karel Boženek, jako umělecký vedoucí souboru, v něm hrál na violu da gamba. Nahrávky byly zachyceny Československým rozhlasem i Československou televizí a stále se občas objevují ve vysílání. ${ }^{16} \mathrm{~V}$ osmdesátých letech, jako pracovník Slezského muzea, úzce spolupracoval s ostravským Krajským kulturním střediskem na pořádání muzikologických konferencí Janáčkiana nejen svými příspěvky, které zde přednesl, ale zvl. redigováním konferenčních sborníků.

Karel Boženek, dobře disponovaný pro práci v „uzavřeném prostoru čtyř muzejních stěn“, kterou si ale vždy dovedl kompenzovat stykem s hudebnickou praxí, na konci osmdesátých let podlehl lákavé nabídce práce dramaturga opery a baletu v tehdejším Státním divadle v Ostravě, kterou pak přijal v roce 1987. Po změně politické situace v našem státě a po personálním „zemětřesení“ v centrální koncertní a divadelní agentuře Pragokoncertu a jejím zprivatizování, přešel sem v roce 1991 na místo dramaturga vážné hudby. Každotýdenní pravidelné dojíždění z Opavy do Prahy přerušil po necelých dvou letech Boženek čerpáním neplacené dovolené, během které vykonal několikaměsíční vědeckou stáž na australské Quisland University v Brisbane. Po návratu z Austrálie se do pražského Pragokoncertu nevrátil a přijal místo odborného asistenta v Ústavu historie a muzeologie na Filozoficko-přrírodovědecké fakultě nově zřízené Slezské univerzitě v Opavě.

V roce 1999 se stal prvním úspěšným absolventem doktorského studia Hudební teorie a pedagogika na Pedagogické fakultě Ostravské univerzity ${ }^{17}$ po obhájení disertace Hudebni muzeum (školitel doc. PhDr. Miroslav Malura). O dva roky později úspěšně prošel habilitačním řízením (habilitační práce Opavská opera) a stal se docentem v oboru Hudební teorie a pedagogika. V roce 2010 ukončil na Slezské univerzitě v Opavě řádný pracovní poměr a působí zde jen externě. Ovšem jeho bohatých znalostí a zkušeností dnes více využívá katedra hudební výchovy Pedagogické fakulty Ostravské univerzity nejen pro vědeckou výchovu studentů jako externího školitele doktorandů, kteří se zabývají ve svých disertačních pracích příbuznou problematikou, ${ }^{18}$ ale zvláště i pro práci v Centru studií regionální hudební kultury, jehož je externím členem.

Karel Boženek, jenž se vloni dožil v dobré duševní i tělesné kondici krásné osmdesátky, může s radostí bilancovat: celoživotně se zabýval hudební regionalistikou slezské oblasti a pravidelně se účastnil (pokud mu to „režim“ povolil) tuzemských i mezinárodní vědeckých konferencí z oboru muzikologie a muzeologie, např. v Praze, Brně, Bratislavě, Katovicích, Bonnu, Cieszyne). Ve své publikační činnosti reflektuje aktuální dění a osobnosti hudby 18. až 20. století celého regionu Slezska, zvl. však Slezska českého,

16 Spolupráce s Českým rozhlasem v Ostravě se ale velmi rozšírila až v posledních dvaceti letech, kdy Boženek připravuje pravidelně hudební pořady na stanici ČRo Vltava.

17 V době tzv. normalizace nemohl z politických důvodů Boženek absolvovat vědeckou aspiranturu a získat titul kandidáta věd (CSc.).

18 Pod jeho školitelským vedením získali titul Ph.D. dosud PhDr. Tomáš Thon a Mgr. Petr Lyko. 
tj., Opavska, Těšínska, ale i Ostravska apod. Autorsky se podílel na př́ípravě vybraných hesel Slovniku české hudebni kultury a Českého hudebniho slovniku osob a institucí. Je autorem desítky knih a více jak stovky studií a statí v hudebních časopisech a sbornících i hudebně-slovních rozhlasových pořadi̊ na stanici Vltava. Jeho dlouholetá práce muzejníka v hudebním oddělení Slezského muzea a charakter jeho školení muzikologa a muzeologa se projevily v multioborovém propojení zákonitostí práce s pramennými materiály hudební povahy (a samozřejmě jejich interpretací) s procesem muzealizace, v němž odhaluje značnou výchovně-vzdělávací potenci.

\section{Bibliography}

175 Slezského muzea v Opavě (1814-1984). 1. vyd. Opava: Slezské muzeum, 1989.

BOŽENEK, Karel. Český hudebně historiografický výzkum regionu bývalého rakouského Slezska.

In Acta historica et museologica Universitatis Silesianae Opaviensis, roč. 4, 1999, s. 5-20.

BOŽENEK, Karel. Prolegomena k hudební kultuře Slezska. In Universitatis Silesiane Opaviensis, roč. 3, 1998, s. 371-398.

BOŽENEK, Karel. Vývoj slezské hudební kultury. In Slezsko. Opava: Matice slezská, 1992, s. 139-152.

GREGOR, Vladimír - STEINMETZ, Karel. (eds.) Hudebni kultura na Ostravsku po roce 1945. 1. vyd. Ostrava: Profil, 1984.

HELFERT, Vladimír. Státni hudebně historický ústav. 1. vyd. Praha: Matice umělecké besedy, 1945.

IVÁNEK, Jakub - SMOLKA, Zdeněk (eds.). Kulturně-historická encyklopedie českého Slezska a severovýchodni Moravy. 2. rozšířené vyd. Ostrava: Ústav pro regionální studia Filozofické fakulty Ostravské univerzity, 2013.

MAZUREK, Jan - STEINMETZ, Karel. et al. Ostravská hudebni kultura od konce 19. století do současnosti. 1. vyd. Ostrava: Ostravská univerzita - Pedagogická fakulta, 2010.

STEINMETZ, Karel - BOŽENEK, Karel - MAZUREK, Jan. Ivo Stolařik. Osobnost hudebni Ostravy. Ostrava: Montanex, 2006.

ŠEVČÍKOVÁ, Veronika et al. Hudebni teorie a pedagogika na Ostravské univerzitě (1995-2011). 1. vyd. Ostrava: Ostravská univerzita - Pedagogická fakulta, 2011. 
